Article

\title{
Determination of Farmers' Willingness to Pay for Sustainable Agricultural Land Use in the GAP-Harran Plain of Turkey
}

\author{
Mustafa Hakkı Aydoğdu ${ }^{1}$, Mehmet Reşit Sevinç ${ }^{2, *}$ (D) Mehmet Cançelik ${ }^{3}$, \\ Hatice Parlakçı Doğan ${ }^{1}$ (D) and Zeliha Şahin ${ }^{1}$ \\ 1 Department of Agricultural Economics, Faculty of Agriculture, Harran University, 63050 Şanlıurfa, Turkey; \\ mhaydogdu@harran.edu.tr (M.H.A.); hparlakcidogan@yahoo.com (H.P.D.); zelihasahiin@gmail.com (Z.Ş.) \\ 2 Department of Bozova Vocational School, Harran University, 63850 Şanlıurfa, Turkey \\ 3 Department of Social Science Vocational School, Harran University, 63200 Şanliurfa, Turkey; \\ m.cancelik@harran.edu.tr \\ * Correspondence: rsevinc@harran.edu.tr; Tel.: +90-414-3183749
}

Received: 9 July 2020; Accepted: 3 August 2020; Published: 5 August 2020

check for updates

\begin{abstract}
There is a risk of salinity and degradation in soil structure due to excessive irrigation in the GAP-Harran Plain. The purpose of the research is to determine farmers' willingness to pay (WTP) for applications of sustainable agricultural land usage practices to avoid salinization in soil based on irrigation problems related to the demands of the farmers', their needs, and which factors affect their willingness to accept payment. The basic material of the research was obtained through face-to-face questionnaires from farmers who were selected by a method of simple random sampling in 2018. Heckman's two-stage model was used in the analysis of the data in Stata. According to the results obtained from the research, $27.85 \%$ of the participants indicated WTP and the average amount was USD 16.2/hectare. The average WTP is calculated as USD 4.43/hectare for all participants and 735.38 thousand USD/year for the whole plain. The agricultural income, household size, farming experience, land amount, non-agricultural income, education level, working in the non-agricultural sector, and membership of farmers' union were determined as statistically effective factors. It is necessary to raise the awareness of farmers through extension services. As awareness increases, both WTP and the adoption of applications will increase. The results supply useful data for people working on this subject for the planning and implementation of sustainable usage of resources in Turkey and to regions with similar socio-economic characteristics. This study is the first of its kind in GAP-Harran, Turkey.
\end{abstract}

Keywords: sustainable agricultural land usage; salinity and degradation in the soil; WTP; GAP-Harran Plain; Turkey

\section{Introduction}

Agriculture is a strategic sector for all countries for reasons such as food safety, raw material supply to other sectors, and employment. Environmental and agricultural sustainability, as well as food safety, are some of the most global issues of concern in recent times [1]. Sustainability is based on economic, social, and ecological factors. A sustainable agricultural environment is needed for sustainable agriculture. The main factors of agriculture are soil, climate, water resources, and nutrients. Of these four basic factors, the conservation of water and soil resources are most suitable for farmer intervention [2]. Excessive cultivation and irrigation cause salinity problems along with structural deterioration in the soil, causing loss of income due to yield-reducing, which is resulting in agricultural sustainability problems. Sustainability is not only economic and social but also a 
moral responsibility [3], which is imperative for the protection of the rights of the next generations. Large-scale project implementations that are not based on adequate sustainable methods can adversely affect the environment and living beings [4,5]. Sustainable usage of the resources can only be a provided that the rate of renewal of these resources is not exceeded. This requires planning economic activities in the short, medium, and long term [6].

Agricultural activities are at the core of rural life and are the most important factor in making a living, which directly affect the level of welfare. The need to conserve resources is balanced by the farmer's need to strive for livelihoods $[7,8]$. However, ecological sustainability could be ignored in low-income regions and countries where economic development is gaining more importance [9]. This situation, which increases the income of the farmer in the short term, causes the sustainability problem due to environmental pollution and structural deterioration in the soil because of the excessive use of agricultural resources in the following periods. According to the Status of World's Soil Resources, among the 10 most important soil threats that endanger ecosystem functions, goods, and services are salinity and alkalinity in the soil [10]. Soil salinity levels vary widely from one environment to another [11]. The salinity problem is expected to affect the world more strongly and intensely in the future [12]. Salt-affected soils are distributed throughout the world, especially in arid and semiarid regions [13]. There are many sources of soil salinity. Natural soil salinity occurs in semi-arid and hot arid climates where annual rainfall is less than $270 \mathrm{~mm}[14,15]$. Soils with shallow water tables could develop soil salinity because of excessive evaporation of water and salt concentration. Globally, unsuitable water quality and irrigation applications also contribute to the salinity of thousands of ha of agricultural land each year. There are 952.2 million ha of salt-affected soil worldwide. These soils constitute approximately $7 \%$ of the total land and approximately $33 \%$ of the potential agricultural land in the world $[14,15]$. Soil salinity is one of the most important problems in the world due to reducing plant growth and the amount of agricultural production. The worldwide amount of arable land is about 1.5 billion ha, of which 77 million ha are not suitable for crop growth due to high salinity [16]. The amount of soil with salinity increases in many parts of the world where there are high temperatures and evaporation rates with low precipitation, especially in dry and semi-arid conditions. Soil salinity turns the fertile soil into unproductive soil, resulting in economic loss [16,17].

A significant part of agricultural land in Turkey is under the influence of arid and semi-arid climatic conditions that depend on natural factors. Besides, due to the impact of human activities, it faces various problems, such as salinity, erosion, and desertification. Since annual precipitation is not sufficient to wash the salts in the soil in terms of both quantity and distribution throughout the year, salinity increases and this speeds up the desertification. Especially in areas where irrigation culture is not developed and there is no natural drainage, groundwater levels rise and soils are salted due to excessive water usage. The GAP-Harran Plain in Turkey is one of the most troubled regions in this regard [18]. On the other hand, Turkey is a candidate country for membership in the European Union (EU). According to the EU Water Framework Directive, it is required to take into account environmental costs in the reimbursement of irrigation-based investments. In other words, the environmental cost arising from irrigation is expected to be collected from water users. Such calculations are not made, therefore it is not collected from farmers and all costs are covered by public finance in Turkey. Applications that reduce salinity will have positive results in terms of both farmer income and public finance.

The Southeastern Anatolia Project (GAP is the Turkish abbreviation) is conducted based on land and water resources in the Southeastern Anatolia Region, which is Turkey's largest integrated regional development project. The GAP project covers 22 dams, 19 Hydroelectric Power Plants (HEPPs), and irrigation of 1.8 million ha agricultural land with a budget of USD 32 billion [19]. The main purpose of GAP is to increase the welfare level of the region and eliminate the development gap with the other regions of Turkey by using the water and soil resources of the region optimally in a sustainable way. Participatory sustainable human development is aimed at the basis of the GAP project. The GAP region is the second least developed region of Turkey [19]. The Harran Plain is the most important plain of the 
GAP project with an area of approximately 166,000 ha in the Şanllurfa province [19]. The geographical locations of Şanlıurfa and the Harran Plain in Turkey are shown in Figures 1 and 2.

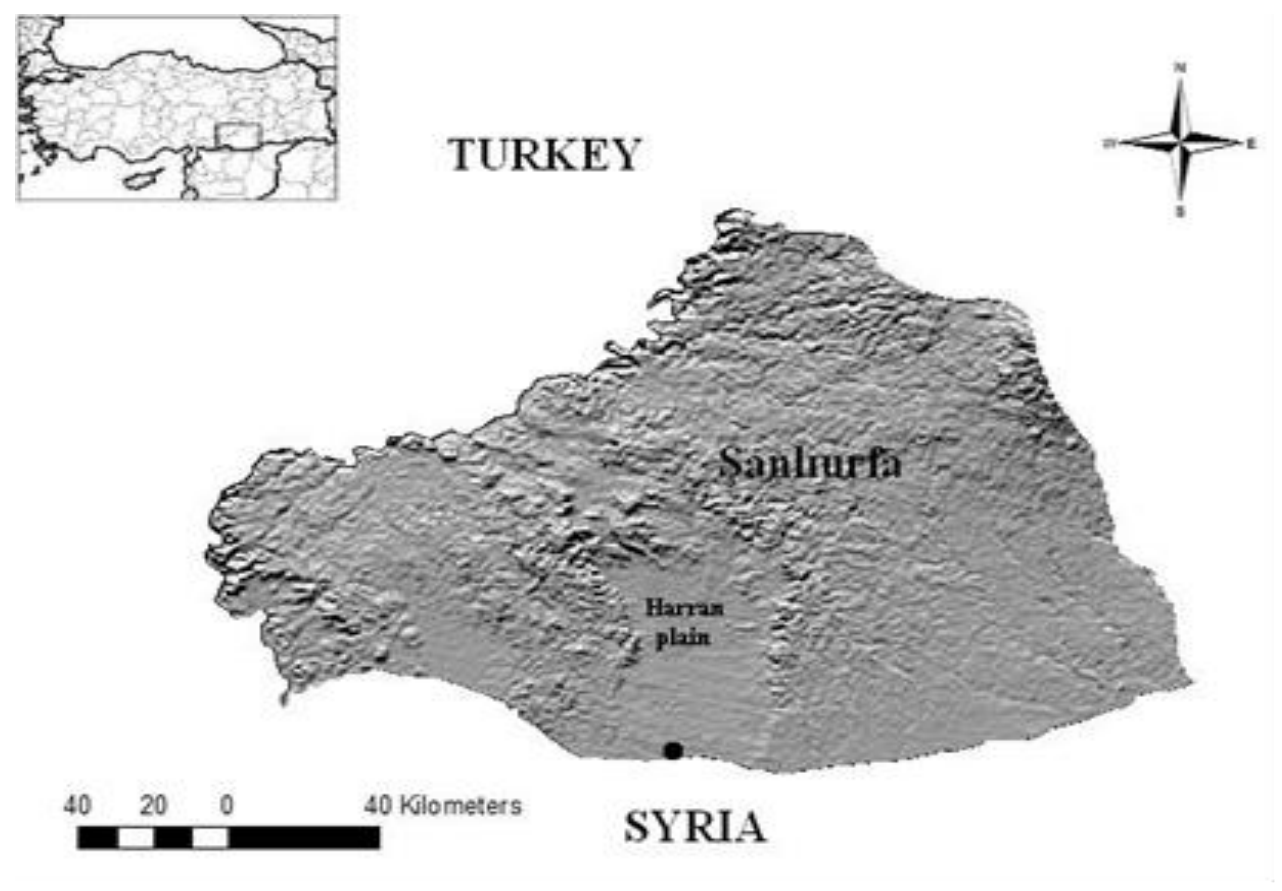

Figure 1. The places Şanlıurfa and Harran Plain in Turkey (Source: Prof. Dr. M. Ali Çullu, Faculty of Agriculture, Harran University).

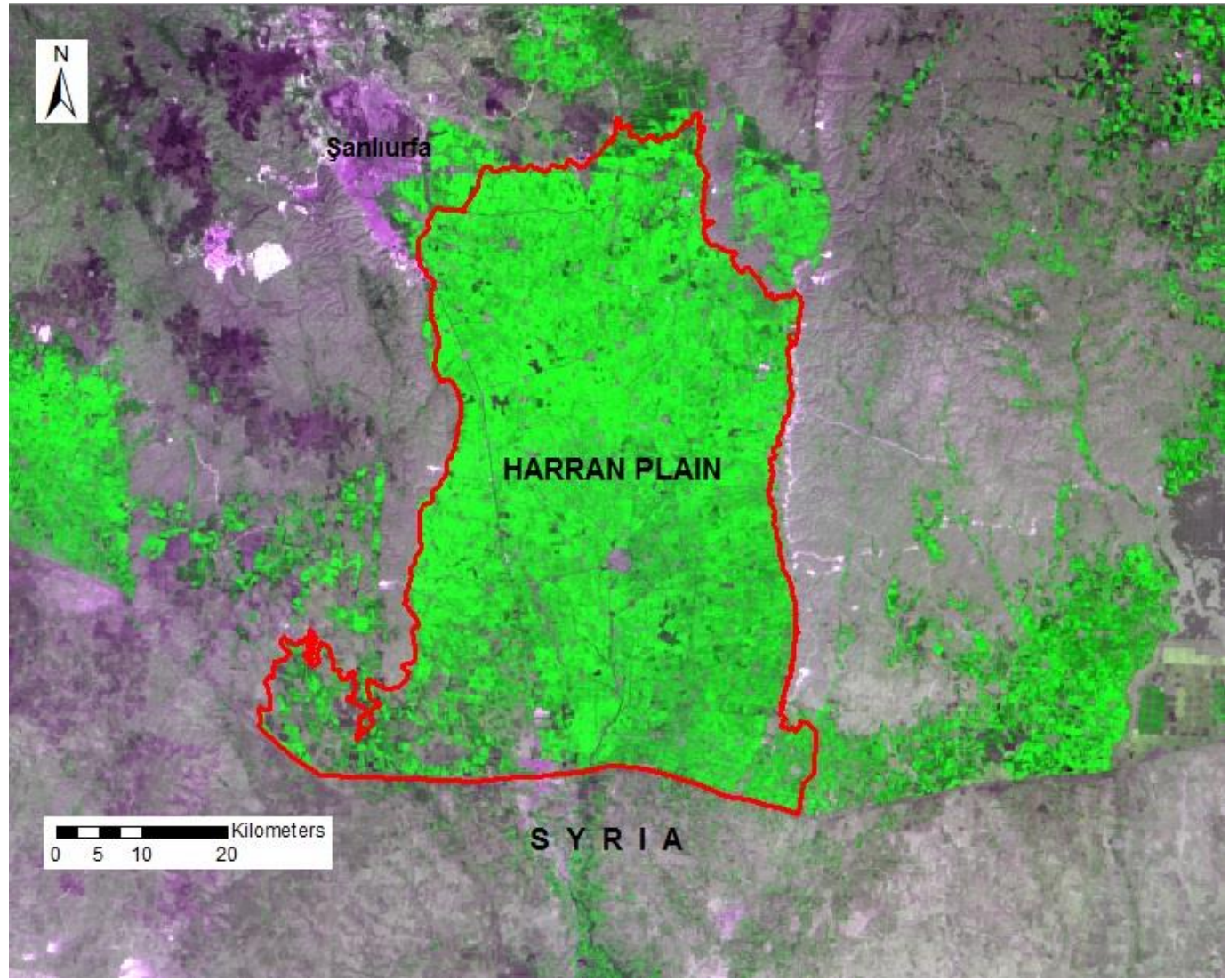

Figure 2. Harran Plain irrigation areas (Source: Prof. Dr. M. Ali Çullu). 
The long term average precipitation of the Harran plain is between $310-350 \mathrm{~mm}$ and evaporation is $1780 \mathrm{~mm}$. It has a rather low slope in general with some pit areas and heights of hilly type [20]. Within the scope of GAP, agricultural irrigations first started in the Harran Plain in 1995 on an area of 30,000 ha. Through irrigation, there was a significant increase in agricultural income in the plain where $88.5 \%$ surface (wild) and $11.5 \%$ pressure (sprinkler and drip) irrigation exists. With the expansion of irrigation areas depending on time, the rate of excessive surface irrigation has also been increased, as shown in Figure 3a, which caused water ponding due to limited natural drainage, as shown in Figure $3 b$.

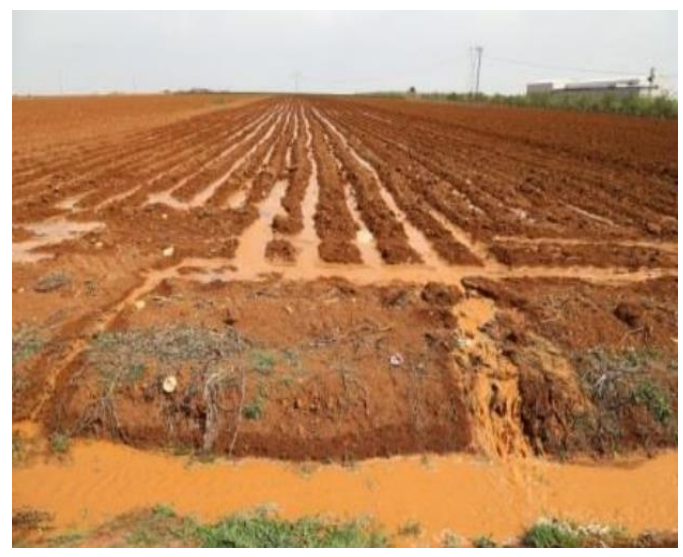

(a)

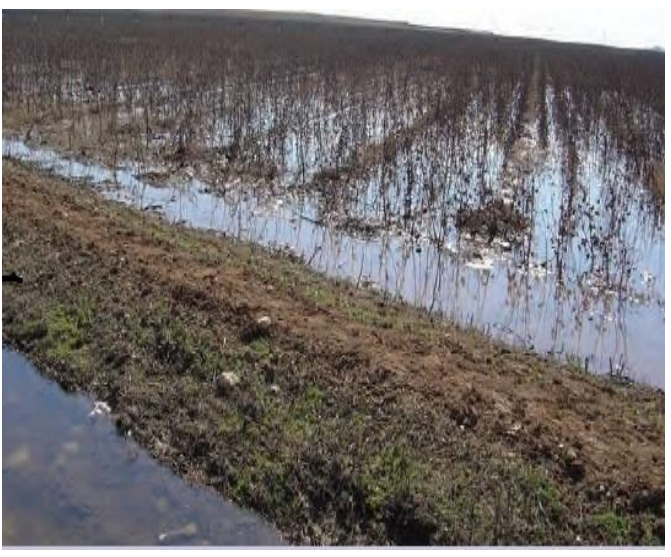

(b)

Figure 3. (a) Excessive surface irrigation in Harran Plain [21]; (b) Water ponding due to limited natural drainage in Harran Plain [22].

This led to salinization problems, shown in Figure $4 a, b$, due to an increase in the groundwater level and high evaporation which resulted in a decrease in productivity and therefore income [23,24]. Operation-based problems in Harran Plain irrigations have been affecting irrigation performance, and excessive drainage water occurs [25]. There is limited natural drainage in the Plain. As a result of the uncontrolled and unconscious irrigation practices in the GAP project, the project also had negative effects on the environment [26]. Due to excessive irrigation in the Harran plain, water failure problems have been observed in the lower parts, and salinity problems have been observed in the central and lower parts of the plain. As a natural consequence of this, product losses are experienced in some areas as a result of rising water levels and some areas due to water failure.

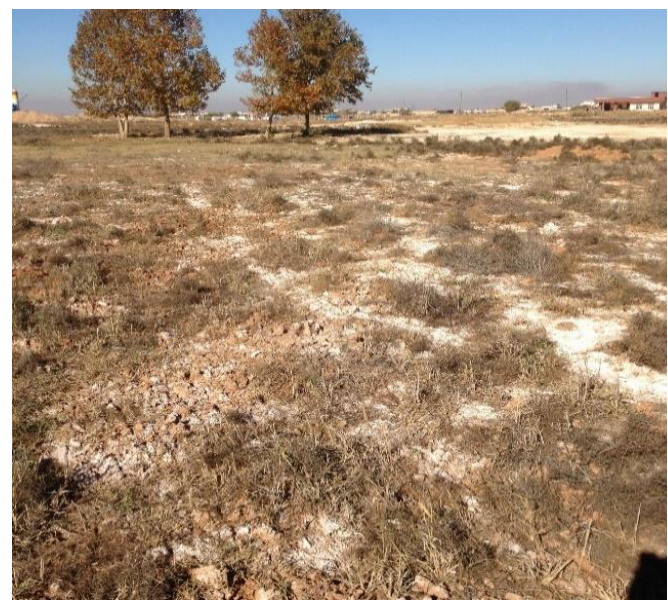

(a)

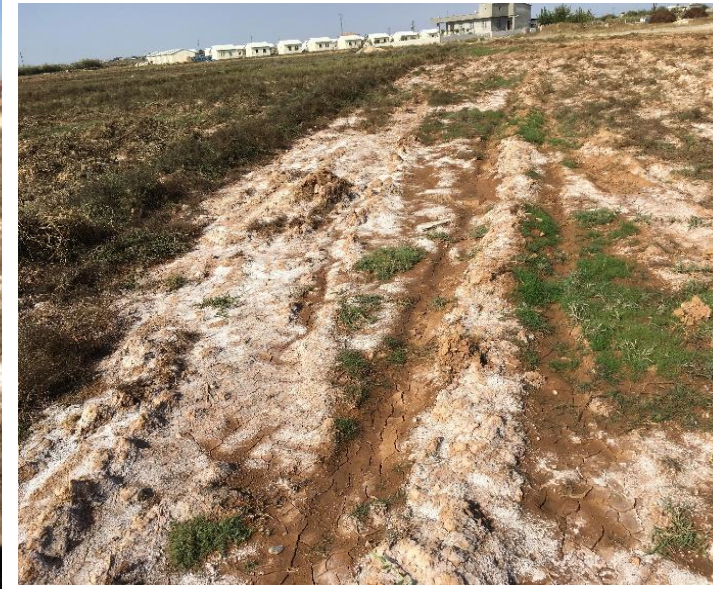

(b)

Figure 4. $(\mathbf{a}, \mathbf{b})$ Salinization problems in different locations of Harran Plain (Source: Prof. Dr. M. Ali Çullu). 
In a study conducted in the field of research, it was determined that increased salinity due to uncontrolled surface irrigation also affects plant yields due to the topographic features and climatic structure suitable for salinity formation in the Harran Plain. The medium salinity resistant cotton plant started to show a decrease in yield due to the increase in salinity intensity in the plain. It was determined that the cotton yield, which is $5340 \mathrm{~kg} / \mathrm{ha}$ in places with low salinity value, decreased to $1840 \mathrm{~kg} / \mathrm{ha}$ in places with the high salinity in the Imambakir Irrigation Union area in the central region of the plain [27]. In the research carried out by the same researchers in the Akçakale district, located to the south of the Harran Plain, it was determined that salinity values in some areas significantly affect the yield of plants due to wild irrigation, high groundwater level, evaporation, and salinity. According to the research result, in 2009, 1,841,000 tons of product and USD 936,000 revenue loss occurred due to salinization [28].

The Harran Plain is considered as a whole in agricultural irrigation within the scope of GAP. However, the Harran Plain is not homogeneous in terms of topography, cultural structure, and farmers' behaviors. Economic growth-targeted development projects, implemented regardless of human beings, the social relations they live in, and the ecological environment have not achieved the desired welfare increase. On the contrary, it has brought some social and environmental negative effects. Due to these negative effects, the economic growth target in the long term has not been achieved with sufficient efficiency. In regions where irrigation and ecological environment culture is not sufficiently developed, opening up large areas to irrigation also brings environmental problems and costs. Although the basis of irrigation related problems in the Harran plain is salinity, the reasons leading to this problem differ. These problems arise from the topography of the irrigated area, limited availability of natural drainage, high groundwater level, the irrigation method applied, cultural differences, and the behavior of the farmers. In other words, these problems differ from farmer to farmer.

The purpose of the research is to determine the willingness of the farmers in the GAP-Harran Plain to pay for the applications of sustainable agricultural land usage practices for avoiding salinization in soil based on irrigation related problems by the demands of the farmers' needs and which factors affect their willingness to accept payment. Previous studies on salinity problems and loss of income have been done on the GAP-Harran plain. However, the subject of the research in this article is being studied for the first time.

\section{Materials and Methods}

The Harran Plain is located within the borders of four districts of Şanlıurfa in different proportions. Accordingly, the population of the Plain was calculated as 233,895 people in 2018, where the main source of livelihood is agriculture and agro-based industry. In other words, almost all of the Plain is directly or indirectly related to agricultural production. For farmers, to benefit from public agricultural supports, they must be registered in the state farmer registration system. Since the registration is annual, the registered number of farmers varies depending on the year. If the farmer does not want to benefit from the agricultural support of that year for various reasons (e.g., letting his land fallow that year, inadequate support, lots of procedures, small land amount, property problems, etc.), he is not registered in the system for that year. However, this does not mean that he is not a farmer.

The research is based on primary data sources. The main material of the research was obtained from questionnaires that were done by the registered farmers face-to-face in the plain on a voluntary participation basis. In total, 15,114 farmers were registered in the state farmer registration system in the Harran Plain in 2018. Farmers were selected by a method of simple random sampling by using the sampling volume table [29], with a $95 \%$ level of confidence and a 5\% error margin. The sample size was 377 among 15,114. The questionnaires were conducted in 2018.

Several independent variables may be used in observational settings to control for bias in the estimation of effects on the dependent variable, which are conditional on certain covariates. The approaches differ in statistical assumptions they make and the methods they apply to the data. The observed covariates are fixed characteristics of each participant and they cannot be manipulated 
by the researcher [30]. The Heckman model assumes that the functional form of the causal relationship between outcome, treatment, and covariates is linear and the model offers no guidance as to the covariates that should be included in its selection function [30].

Many factors affect farmers' attitudes, behaviors, and decisions that come from the nature of agriculture and rural life. Since the dependent variable is WTP for the research, the participant needs to get something more in return for this payment and this must be meaningful for them. The set of independent variables that can affect it most was created based on demographic and economic factors. The independent variable of interest must be a significant predictor in the first stage of a model for sample selection bias to exist [31]. The most important factor affecting WTP is the ability to pay, which is influenced by income and expenses for the livelihood of the household. There are different sources of income in rural areas. Although the number of these may be more, the livestock, the amount of land, the number of households working, and non-agriculture are among the most important. On the other hand, age, farming experience, and education level also affect income. On the basis of subsistence, costs are marital status, number of households, farm expenditures (land amount and livestock), and costs based on age and education level. Most of the authors have been regularly researching different topics in the same field since 2006. In regular research, it was determined that around $95 \%$ of farmers are married. Therefore, marital status was not chosen as a variable. Another feature of the research area was the lack of interest in the organized structure that was formed for many reasons [32]. To be effective in determining the attitude of the farmer, membership of farmer's union was chosen as a variable, too. The number of these factors can be increased, but farmers often do not participate in long-term survey interviews in the research area. Depending on these assumptions, the questionnaires covered questions to estimate the WTP of the farmers for the use of sustainable agricultural land, the farmers' demographics and socio-economic characteristics, and their affordability.

This study was aimed at estimating the factors affecting the WTP of the farmers who participated in the survey. Firstly, the farmers must accept the invitation to participate in the payment to make these estimations. Therefore, if the condition of the farmer to participate in the payment is not taken into account while making the estimation, the problem of sample selection bias arises and the obtained parameters will be biased. Thus, the first stage is aimed at determining whether farmers are willing to participate in the payment for sustainable agricultural land usage practices for avoiding salinization in soil, based on irrigation related problems. Then, the second stage was aimed at determining the factors affecting the payment levels of those who participated in the WTP. Therefore, the research was modeled in two stages. Because of this two-stage feature of the study, the Heckman's two-stage estimation method was used in the analysis of the data. Heckman models account for sample-induced endogeneity but are not effective when other sources of endogeneity are present [31]. The first stage of the method was a typical binary selection probit model of whether farmers have participated in the WTP [33-36]. In the first stage, the "selection equation" - that is, the participation in the payment equation-is estimated by using the maximum likelihood method. At this stage, reverse Mills rates are obtained for each individual [37], modeled as follows (1):

$$
P(0,1)=\beta_{0}+\beta_{1} X_{1}+\beta_{2} X_{2}+\ldots \ldots+\beta_{n} X_{n}+\varepsilon_{i}
$$

In formula (1), $P$ shows the declared variable. If the farmer has participated in the WTP, it is shown as 1 ; if not, it is indicated with $0 . \beta_{0}$ is constant, $\beta_{0} \ldots \ldots \beta_{n}$ are the regression coefficients of variables, $X_{1} \ldots \ldots X_{n}$ are the explanatory variables, and $\varepsilon_{i}$ shows the term of error. The second stage is the ordinary least square approach, which tries to explain the factors affecting the payment levels if the farmers have participated in the WTP [33-36]. Heckman models should include at least one variable in the first stage that does not appear in the second stage [38]. The excluded variable was chosen as membership of the farmer's union in this research due to assuming that this was the least affected variable among the others on farmers' WTP. In the second stage, this was again estimated by 
the maximum likelihood method through the vector of the model variable, whose sample selection bias is corrected and the Mills rate obtained from the first stage [37,39], modeled as follows (2):

$$
Y_{i} \mid P>0=\beta_{0}+\beta_{1} X_{1}+\beta_{2} X_{2}+\ldots \ldots+\beta_{n} X_{n}+\beta_{n+1} \lambda+\varepsilon_{i}
$$

In formula (2), $Y_{i}$ shows the disclosed variable-i.e., the level of payment of farmers. $\beta_{0}$ is constant. $\beta_{0} \ldots \ldots \beta_{n}$ are regression coefficients of variables, $X_{1} \ldots \ldots X_{n}$ are descriptive variables and $\varepsilon_{i}$ shows the term of error. In formula (2) $\lambda$ (lambda) shows the rate of Mills, which stands for potential sample selection bias calculated as sigma multiplied by rho, where sigma represents the standard deviation of the residuals in the second stage and rho is the correlation between the error terms in the first and second stage equations and is widely used in the research. On the other hand, a study concluded that the significance of lambda alone does not indicate sample selection bias [31], but is still an important indicator. Detailed information about the model is available in the references given in this section.

\section{Research Findings and Discussion}

The average age of the farmers surveyed was 46.6 years; $94.5 \%$ were married, $3.2 \%$ were single, and $2.3 \%$ were widows. The average number of households of the participants was 7.9 . The average number of people working in agriculture was 4.6 and the number of non-agricultural workers was 0.66 . The average farming experience was 22.3 years. The average amount of agricultural land cultivated by farmers was 17.83 ha and the average agricultural income declared by the farmers was 105,548 TL(Turkish Lira)/year (21,897.9 USD/year). Income declared by farmers was divided into average land size and hectare-based values were calculated as $5919.69 \mathrm{TL} / \mathrm{ha}$ (1228.14 USD/ha). The average income of those with non-agricultural income declared by the farmers was 37,456 TL/year (7770.95 USD/year) and the average non-agricultural income for all participants was calculated as $4272 \mathrm{TL} /$ year (886.31 USD/year). The average currency of USD 1 is equal to TL 4.82 in 2018 in Turkey [40]. The descriptive statistics of the surveyed participants are shown in Table 1.

$20.43 \%$ of farmers believe that the more water they use, the more yield will be achieved, while $26.26 \%$ have no idea about it. In total, $53.31 \%$ of farmers believe that excessive irrigation would lead to a loss of yield. While the rate of those who believe that the productivity decreases in agricultural land was $50.66 \%$, the rate of those who disagree with this was $27.84 \%$ and the rate of those who have no idea about it was $21.5 \%$. The first phase of the model, was aimed at determining the WTP of farmers. The proportion of those who had WTP for sustainable agricultural land use among all participants was $27.85 \%$. The rate of those who had no idea was $37.40 \%$ and the rate of those who had no WTP was $34.75 \%$. The average amount of those who were WTP was calculated as $78.06 \mathrm{TL} / \mathrm{ha}$ (USD 16.2/ha), and the average WTP for all participants was $21.33 \mathrm{TL} / \mathrm{ha}$ (USD 4.43/ha). On the other hand, this amount was lower than the expectations before the research. This was not about solvency; it was about WTP directly. For the WTP, the risk perception of the farmer should be formed. In the study conducted in Şanlıurfa, it was determined that $53 \%$ of farmers have a perception of risk about climate change and $62 \%$ of farmers accepted to pay USD 75.07/ha for adaptation practices to reduce its potential effects [41]. This result confirms that the WTP and the amount of payment increases due to the increased risk perception.

The Heckman's first-stage model, Probit model/selection model, estimation results are shown in Table 2. Regarding the willingness of the surveyed farmers to pay for sustainable agricultural land use, the reference variables for each group of independent variables are located in Table 2 . The LR chi-square value of the model was calculated as 58.24 and the $p$-value as 0.000 . In the model, the Pseudo- $R^{2}$ value is $13 \%$, which was calculated for the measure of goodness of fit in the model. This value is an indicator of the effectiveness of the variables in the model in explaining the dependent variable. 
Table 1. The descriptive statistics of the surveyed participants.

\begin{tabular}{|c|c|c|c|}
\hline Variable & Description & Mean & Standard Deviation \\
\hline Age (Year) & $\begin{array}{l}\text { Age of the farmer, } 1 \text { for } 18-30(6.37 \%), 2 \text { for } \\
31-40(27.06 \%), 3 \text { for } 41-50(31.82 \%), 4 \text { for } \\
51-60(21.49 \%), 5 \text { for } 61 \text { and more }(13.26 \%)\end{array}$ & $\begin{array}{l}3.082 \\
(46.6 \text { Years })\end{array}$ & 1.126 \\
\hline Household (People) & $\begin{array}{l}\text { Number of households, } 1 \text { for } 1-4(13 \%), 2 \\
\text { for } 5-9(56.23 \%), 3 \text { for } 10 \text { and more }(30.77 \%)\end{array}$ & $\begin{array}{c}2.178 \\
\text { (7.9 Peoples) }\end{array}$ & 0.638 \\
\hline Experience (Year) & $\begin{array}{l}\text { Farming experience, } 1 \text { for } 1-10(15.92 \%), 2 \\
\text { for } 11-20(34.21 \%), 3 \text { for } 21-30(33.16 \%), 4 \\
\text { for } 31 \text { and more }(16.71 \%)\end{array}$ & $\begin{array}{c}2.507 \\
(22.3 \text { Years })\end{array}$ & 0.951 \\
\hline $\begin{array}{l}\text { Working in agriculture } \\
\text { (people) }\end{array}$ & $\begin{array}{c}\text { Household number working in agriculture, } \\
1 \text { for } 1-4(60.47 \%), 2 \text { for } 5-9(27.06 \%), 3 \text { for } \\
10 \text { and more }(12.47 \%)\end{array}$ & $\begin{array}{c}1.520 \\
(4.6 \text { Peoples) }\end{array}$ & 0.707 \\
\hline $\begin{array}{l}\text { Working in } \\
\text { Non-Agricultural }\end{array}$ & $\begin{array}{l}\text { Household member working in the } \\
\text { non-agricultural sector, If No is } 0(65 \%) \text {, Yes } \\
\text { is } 1(35 \%)\end{array}$ & $\begin{array}{c}0.350 \\
(Y e s, 35 \%)\end{array}$ & 0.478 \\
\hline Land amount (Hectare) & $\begin{array}{l}\text { The amount of land cultivated by the } \\
\text { farmer, } 1 \text { for } 1-5(23.34 \%), 2 \text { for } 5.1-10 \\
(27.85 \%), 3 \text { for } 10.1-20(23.61 \%), 4 \text { for } 20.1 \\
\text { and more }(25.2 \%)\end{array}$ & $\begin{array}{c}2.507 \\
(17.83 \mathrm{ha})\end{array}$ & 1.106 \\
\hline Income (TL/Year) & $\begin{array}{c}\text { The average annual income of the farmer } \\
\text { from agriculture, } 1 \text { for TL } 25,000 \text { and less } \\
(21.49 \%), 2 \text { for } 25,001-50,000(20.69 \%), 3 \text { for } \\
50,001-100,000(25.46 \%), 4 \text { for } \\
100,001-200,000(20.68 \%), 5 \text { for } 200,001 \text { and } \\
\text { more }(11.68 \%)\end{array}$ & $\begin{array}{c}2.804 \\
(105,548 \mathrm{TL} / \text { year; } \\
21,897.9 \text { USD/year })\end{array}$ & 1.306 \\
\hline Education Level & $\begin{array}{c}\text { The education level of the farmers, } 1 \text { for } \\
\text { literate }(14.59 \%), 2 \text { for primary school } \\
(48.81 \%), 3 \text { for secondary school (15.65\%), } 4 \\
\text { for high school }(12.73 \%), 5 \text { for university } \\
(8.22 \%)\end{array}$ & $\begin{array}{c}2.512 \\
(\text { Level) }\end{array}$ & 1.137 \\
\hline Commercial Livestock & $\begin{array}{l}\text { Does the farmers have commercial } \\
\text { livestock? No is } 0(89.66 \%) \text {, Yes is } 1(10.34 \%)\end{array}$ & $\begin{array}{c}0.103 \\
(\text { Yes, } 10.34 \%)\end{array}$ & 0.305 \\
\hline $\begin{array}{l}\text { Membership of Farmer's } \\
\text { Union }\end{array}$ & $\begin{array}{l}\text { Is the farmer a member of any farmer } \\
\text { union? No is } 0(34.22 \%) \text {, Yes is } 1(65.78 \%)\end{array}$ & $\begin{array}{c}0.658 \\
(\text { Yes, } 65.78 \%)\end{array}$ & 0.475 \\
\hline Non-agricultural income & $\begin{array}{l}\text { Does the farmer have a non-agricultural } \\
\text { income? No is } 0(88.59 \%) \text {, Yes is } 1(11.41 \%)\end{array}$ & $\begin{array}{c}0.114 \\
(\text { Yes, } 11.41 \%)\end{array}$ & 0.318 \\
\hline
\end{tabular}

According to the model results in Table 2, a statistically significant relationship exists between the independent variables - which are experience, agricultural income, education level, membership of farmer's union, and non-agricultural income-and sustainable agricultural land usage, which as a variable was dependent on the WTP of the farmers.

Farmers between 18 and 30 years old were taken as the reference in the age variable groups. Except for the sub-group between the ages of 51 and 60, other groups have less WTP. However, there was no statistically significant relationship observed in the age variable. A study conducted in the southern part of Turkey about farmers' sustainable agriculture perceptions also concluded that age was not an effective factor [42]. On the other hand, a study concluded that age was determined as an effective factor in assessing ecologically sustainable agricultural land-use in France [43]. In the research for sustainable ecosystem-based income in China, age was found to be an effective factor for WTP [44]. Households with the number of people between 1 and 4 were taken as the reference group. In this variable, a number of people in the household between 5 and 9 negatively shows WTP, while those of a household number of 10 and above have a positive WTP. However, no statistical significance was observed in the household variable. A study conducted in the south of Turkey also found that family size was not an effective factor [42]. Farmers with between 1 and 10 years of farming experience were taken as the reference in this variable. All subgroups approach the WTP negatively. As farming experience increases, farmers' ability to cope with problems increases. Therefore, the WTP decreases. 
Farmers, who are among the sub-groups of this variable, with experience between 11-20 years, approached WTP more negatively at $p<0.01$ significance level.

Table 2. The Heckman's first-stage model, Probit model/selection model, estimation results.

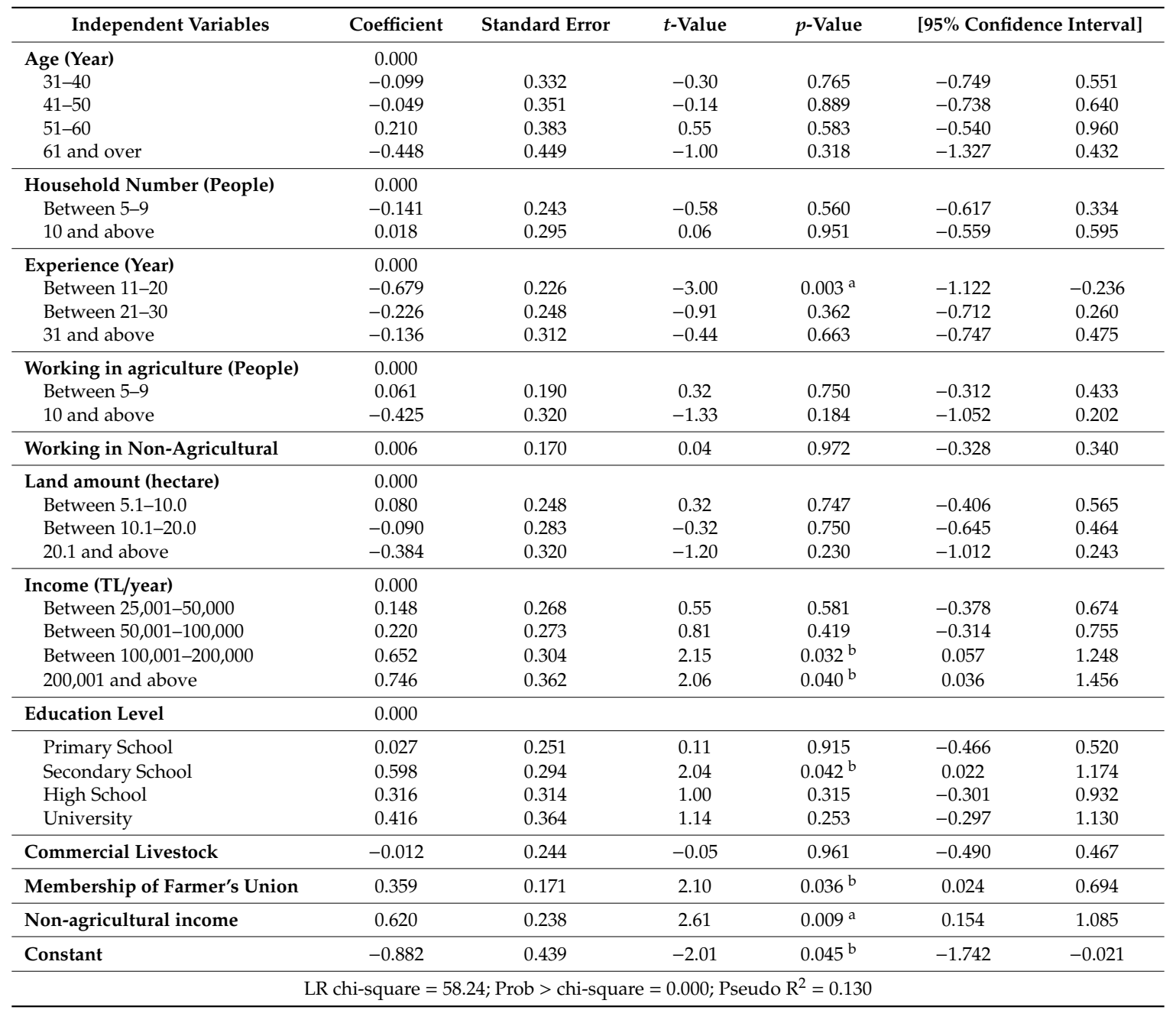

The reference groups of variables, which are taken as a basic level: those between "18 and 30" for age, " $1-4$ " for households, "1-10" for experience, "1-4" for working in agriculture, "yes" for working in non-agriculture, " 5 ha and less" for land amount, "25,000 and under" for income, "literate" for education, "yes" for commercial livestock, "yes" for membership for farmer's union, "yes" for non-agricultural income. a,b Orderly indicates the degree of the statistical significance level of 0.01 and 0.05 .

Households with between 1 and 4 people working in agriculture were taken as the reference group for the number of people working in agriculture. Statistical significance was not detected in this variable. Households with between 5 and 9 people working in agriculture had more positive WTP. However, a negative relationship was observed in households with 10 or more people working in agriculture. In such crowded families, the household labor force has the opportunity to work for a fee outside their businesses. Similar results were concluded in a study about sustainable agricultural income conducted in the same region [36]. Those who work outside the agriculture in the households of the farmers are taken as the reference group. Those who are not employed in the farmer's households other than agriculture have more positively WTP because they do not have any income other than agriculture. However, no statistical significance was observed in this variable. Landowners of 5 ha and below were taken as the reference group in the variable of the land amount. The WTP for farmers, whose land is between 5.1 and 10 hectares, is positively increasing. The average size of agricultural holdings in Turkey is around 6 hectares [45]. Farmers in this group have been trying to increase their 
welfare levels with subsistence agriculture. Therefore, they have more WTP so that their welfare levels are not adversely affected. As the amount of land increases, the willingness to participate in payment negatively increases, but no statistical significance was observed in this variable. The same result was obtained in research conducted in the south of Turkey [42]. On the other hand, it was determined that the amount of land is an effective factor in the WTP for the protection of agricultural lands in China [46], sustainable agricultural production in Indonesia, and Uganda [47,48], and safe agricultural production in Taiwan [49].

An annual income of TL 25,000 and below was taken as the reference in the variable of income. When the farmer's agricultural income increases, the willingness to participate in payment for sustainable agricultural land usage increases. There were statistically significant relationships that exist in the groups of an annual income of over TL 100,000 with a statistical significance level of $p<0.05$. As the income level of the farmers increases, the WTP increases to continue living better and not to lose welfare [50]. It was determined that the income level of the farmers affects the WTP of the farmers in many studies-for example, reducing risks in sustainable agriculture in Iran [51], to generate sustainable income based on agro-environment in China and Uganda [44,48]. Literate farmers were taken as the reference for the groups of the education variable. As the education level of farmers increases, the willingness to participate in payment increases. A statistically significant relationship was observed on secondary school graduates with a level of $p<0.05$. In studies conducted in the USA, China, and Turkey, education was found to be an effective factor in the WTP for the sustainable ecosystems $[44,52,53]$. On the other hand, education was found not to be an effective factor in a study conducted in the south of Turkey about sustainable agriculture [42]. In the commercial livestock variable, farmers engaged in commercial livestock were taken as reference groups. Farmers who did not engage in commercial livestock had less WTP in a negative way compared to those who did and no statistical significance was observed in this variable. The membership of farmers' unions was taken as the reference group in this variable. Farmers who were not members of any farmers' unions have more WTP. A statistically significant relationship was detected at a level of $p<5 \%$. Memberships to farmers' unions give farmers confidence. In this sense, non-members have more risks. Therefore, they are expected to show more WTP for agricultural land usage. A study conducted in Cameroon concluded that farmers' unions were important for farmers and their rural livelihoods [54]. In studies conducted in the south and southeast part of Turkey and Italy, of which the farmers' union membership was determined to be an effective factor of sustainable agricultural activities [32,42,55], those who have non-agricultural income was taken as the reference group. A statistically significant relationship was detected between those who were not a part of the farmers' union, with the level of $p<1 \%$.

The Heckman's second-stage model, OLS model/payment model, estimation results are shown in Table 3, which shows the relationship between the factors that affected the payment level of the variables used in the model and their subgroups. A Wald chi-square value of the model was calculated as 118.47 and $p$-value as 0.000 . The model was statistically significant as a whole according to these results. Besides, the rate of Mills (lambda) was statistically meaningless. It could be said that there was no selection bias in the model according to these statistical results obtained from Stata. Therefore, the obtained results are reliable.

All the sub-groups in the age variable indicated less WTP concerning the reference group. However, no statistically significant relationship was observed at any subgroup $(p>10 \%)$. As the number of people in a household increased, there was more WTP concerning the reference group in this variable. A statistically significant relationship was determined at each of the subgroups of this variable with a level of $p<5 \%$. In the variable of farming experience, all other sub-groups indicated more WTP concerning the reference group. As farming experience increases, attitude towards the importance of sustainable land increases. A statistically significant relationship was detected at those with 11-20 years of farming experience with a level of $p<1 \%$ and above 30 years' experience with a level of $p<5 \%$ concerning the reference group. Besides, those between 21 and 30 years' experience also showed more WTP concerning the reference group but no statistically significant relationship was detected 
in this subgroup $(p>10 \%)$. The number of people in a household working in agriculture, while the subgroup of 5-9 people working in agriculture, showed less WTP, and 10 and above showed more WTP concerning the reference group. Agriculture is the basic income source in the rural side. As the number of households increases, the need for sustainable agricultural land is higher for the safe income. A statistically significant relationship was not determined in any subgroup $(p>10 \%)$. In the variable of working in non-agriculture, those who had family members working in non-agricultural activities in the household were taken as reference groups. Those who did not have non-agricultural employment in households had more WTP concerning the reference group, with a statistical significance level of $p<5 \%$. The source of income for the farmers who did not have non-agricultural workers in the household was agriculture. Sustainable agricultural land is important for both regular income and household employment.

Table 3. The Heckman's second-stage model, OLS model/payment model, estimation results.

\begin{tabular}{|c|c|c|c|c|c|c|}
\hline WTP & Coefficient & Standard Error & $t$-Value & $p$-Value & \multicolumn{2}{|c|}{ [95\% Confidence Interval] } \\
\hline Age & & & & & & \\
\hline $31-40$ & -1.859 & 1.415 & -1.31 & 0.189 & -4.632 & 0.915 \\
\hline $41-50$ & -0.093 & 1.629 & -0.06 & 0.955 & -3.285 & 3.099 \\
\hline $51-60$ & -1.251 & 1.809 & -0.69 & 0.489 & -4.797 & 2.295 \\
\hline 61 and over & -1.683 & 2.092 & -0.81 & 0.421 & -5.783 & 2.417 \\
\hline Household (people) & 0.000 & & & & & \\
\hline Between 5-9 & 2.272 & 1.098 & 2.07 & $0.039^{b}$ & 0.119 & 4.425 \\
\hline 10 and above & 3.369 & 1.321 & 2.55 & $0.011^{b}$ & 0.781 & 5.957 \\
\hline Experience (year) & 0.000 & & & & & \\
\hline Between 11-20 & 2.674 & 1.583 & 1.69 & $0.091^{\mathrm{c}}$ & -0.429 & 5.777 \\
\hline Between 21-30 & 1.518 & 1.201 & 1.26 & 0.206 & -0.836 & 3.871 \\
\hline 31 and above & 2.896 & 1.446 & 2.00 & $0.045^{b}$ & 0.061 & 5.730 \\
\hline \multirow{2}{*}{ Working in agriculture (people) } & 0.000 & & & & & \\
\hline & -0.099 & 0.850 & -0.12 & 0.907 & -1.765 & 1.567 \\
\hline $\begin{array}{l}\text { Between 5-9 } \\
10 \text { and above }\end{array}$ & 2.147 & 1.835 & 1.17 & 0.242 & -1.449 & 5.743 \\
\hline Working in Non-Agricultural & 1.552 & 0.746 & 2.08 & $0.037^{b}$ & 0.090 & 3.013 \\
\hline Land amount (hectare) & 0.000 & & & & & \\
\hline Between 5.1-10.0 & -2.373 & 1.622 & -1.46 & 0.143 & -5.552 & 0.806 \\
\hline Between 10.1-20.0 & -4.370 & 1.725 & -2.53 & $0.011^{\mathrm{b}}$ & -7.751 & -0.989 \\
\hline 20.1 and above & -4.435 & 2.134 & -2.08 & $0.038^{\mathrm{b}}$ & -8.618 & -0.252 \\
\hline Income (TL) & 0.000 & & & & & \\
\hline Between 25,001-50,000 & 5.325 & 1.885 & 2.83 & $0.005^{\mathrm{a}}$ & 1.630 & 9.019 \\
\hline Between 50,001-100,000 & 6.973 & 1.775 & 3.93 & $0.000^{\mathrm{a}}$ & 3.494 & 10.451 \\
\hline Between 100,001-200,000 & 9.405 & 2.250 & 4.18 & $0.000^{\mathrm{a}}$ & 4.996 & 13.814 \\
\hline 200,001 and above & 11.482 & 2.608 & 4.40 & $0.000^{\mathrm{a}}$ & 6.370 & 16.594 \\
\hline Education (level) & 0.000 & & & & & \\
\hline Primary School & 0.740 & 1.205 & 0.61 & 0.539 & -1.623 & 3.102 \\
\hline Secondary School & 1.313 & 1.675 & 0.78 & 0.433 & -1.970 & 4.596 \\
\hline High School & 1.716 & 1.471 & 1.17 & 0.243 & -1.166 & 4.598 \\
\hline University & -0.141 & 1.651 & -0.09 & 0.932 & -3.378 & 3.095 \\
\hline Commercial Livestock & -0.215 & 1.214 & -0.18 & 0.859 & -2.594 & 2.164 \\
\hline Non-agricultural income & -1.740 & 1.612 & -1.08 & 0.281 & -4.900 & 1.420 \\
\hline Constant & 0.905 & 4.194 & 0.22 & 0.829 & -7.316 & 9.126 \\
\hline lambda & -1.211 & 2.900 & -0.42 & 0.676 & -6.896 & 4.474 \\
\hline rho & -0.384 & & & & & \\
\hline sigma & 3.150 & & & & & \\
\hline Number of obs $=3 ?$ & ensored obs $=$ & 2; Uncensored ob & 5; Wald c & ) $=118.47$ & $>$ chi $2=0$. & \\
\hline
\end{tabular}

All subgroups in the land amount variable indicated less WTP concerning the reference group. The statistical significance level in the land amount of 10.1 to 20 ha and above 20 ha was detected as $p<5 \%$. No statistically significant relationship was observed for farmers with 5.1 to 10 ha of land $(p>10 \%)$. As the acreage of land increased, the WTP decreased. As the amount of land increases, the amount of payment for sustainable agricultural land will increase. In this sense, the farmer does not want to pay more. The high amount of land means more income in a sustainable agricultural environment. However, this situation is not perceived as such for the farmer, and farmers should be informed about this issue. All subgroups of the income variable indicated more WTP concerning the 
reference group, as was expected because, as farmers' incomes increased, their affordability increased. A statistically significant relationship was found in all sub-groups with a level of $p<1 \%$. The most striking result in this variable is that, as the income group rises, WTP increases more. In the variable of education, all other sub-groups, except university graduates, indicated more WTP concerning the reference group. University graduates have less WTP than the reference group. This situation could be explained by the fact that university graduates are more knowledgeable in combating agricultural problems. On the other hand, a statistically significant relationship was not determined in any subgroup $(p>10 \%)$. Those who were involved in commercial livestock were taken as the reference group in this variable. Farmers who were not involved in commercial livestock had less WTP than the reference group as expected. The most important expense in livestock is feed costs [56]. Productive land is needed for feed production and the grazing of animals. No statistically significant relationship was defined in this variable $(p>10 \%)$. In the non-agricultural income variable, those who did not have non-agricultural income indicated less WTP concerning the reference group, where non-agricultural income was the reference group. However, a statistically significant relationship was not defined in this variable $(p>10 \%)$.

\section{Conclusions}

According to the results obtained from this research, factors that statistically increase the farmer's willingness to participate in payments are income (agricultural and non-agricultural income), membership of farmers' union, and secondary school graduates in education level. However, willingness to participate in payment decreases with increasing age and farming experience, and those with 11 to 20 years of farming experience were statistically significant. The factors that statistically increased the WTP for those who agree to participate in the payment were those who had between 5 and 9 households, farming experience, working in non-agriculture, and all income groups, while those who had 10 ha of land and above had statistically reduced WTP. Based on these findings, agricultural extension activities primarily should be conducted to raise awareness of those who have no idea and in subgroups that reduce participation in payment and WTP. As awareness increases, both WTP and the adoption of applications increases. Because nearly a third of farmers have no idea about problems that may arise in irrigation, land, and environmental issues, these activities should be done for all farmers in the Harran Plain. Besides, training, practices and arrangements should be made for the solution of irrigation-based problems according to the needs of the farmer. These measures will positively affect farmers' participation and WTP. In this context, the Harran plain should be analyzed in more detail, not as a whole, but based on subgroups according to the type of problem and farmers' needs.

The average WTP for all farmers participating in the survey was determined as USD 4.43/ha. This amount is approximately \%o4 of the farmer's average annual agricultural income per hectare. Accordingly, the amount calculated for the entire Harran plain (166,000 ha) is USD 735.38 thousand/year. This amount could be used as co-financing in public investments for sustainable agricultural land usage training and practices for avoiding salinization in soil based on irrigation related problems by the demands of the farmers' needs. On the other hand, this amount is the minimum, as the rate of those who had no idea was $37.4 \%$. These are farmers who were located in the upper parts of the Harran plain, yet did not experience irrigation-based soil degradation. If notifications were made through training, these farmers would also be invest in order to save income in the future. This will increase the amount of money to be paid towards the sustainable usage of agricultural land in the Harran plain.

This research is the first study in Turkey made in this regard. The results of this research provide useful data to researchers, decision-makers, and policymakers working on this issue. On the other hand, the results obtained from this study could be used in regions and countries with similar socio-economic characteristics. 
Author Contributions: Conceptualization, M.H.A., M.R.S., and M.C.; methodology, M.H.A., M.R.S., and M.C.; software, M.C. and M.R.S.; validation, M.H.A., M.R.S., H.P.D., and M.C.; formal analysis, M.H.A. and M.C.; investigation, M.H.A., M.R.S., H.P.D., and Z.Ş.; resources, M.H.A., M.R.S., and Z.Ş.; data curation, M.C. and M.H.A.; writing—original draft preparation, M.H.A.; writing—review and editing, M.H.A., M.R.S., and H.P.D.; visualization, M.R.S.; supervision, M.H.A. and M.R.S. All authors have read and agreed to the published version of the manuscript.

Funding: This research received no external funding.

Acknowledgments: In this section you can acknowledge any support given which is not covered by the author contribution or funding sections. This may include administrative and technical support, or donations in kind (e.g., materials used for experiments).

Conflicts of Interest: The authors declare no conflict of interest.

\section{References}

1. WEF (World Economic Forum). The Global Risks Report 2018, 13th ed.; WEF: Geneva, Switzerland, 2018; ISBN 978-1-944835-15-6.

2. Wikipedia. Sürdürülebilir Tarım (Sustainable Agriculture). Available online: https://tr.wikipedia.org/w/index. php?title=S\%C3\%BCrd\%C3\%BCr\%C3\%BClebilir_tar\%C4\%B1m\&oldid=22649129 (accessed on 3 July 2020).

3. Dundon, S.J. Agricultural ethics and multifunctionality are unavoidable. Plant Physiol. 2003, 133, $427-437$. [CrossRef] [PubMed]

4. Zhang, L.; Yan, C.; Guo, Q.; Zhang, J.; Ruiz-Menjivar, J. The impact of agricultural chemical inputs on environment: Global evidence from informetrics analysis and visualization. Int. J. Low Carbon Technol. 2018, 13, 338-352. [CrossRef]

5. Nicolopoulou-Stamati, P.; Maipas, S.; Kotampasi, C.; Stamatis, P.; Hens, L. Chemical pesticides and human health: The urgent need for a new concept in agriculture. Front. Public Health 2016, 4, 148. [CrossRef] [PubMed]

6. Stenholm, C.W.; Waggoner, D.B. Low-input, sustainable agriculture: Myth or method? J. Soil Water Conserv. 1990, 45, 13-17.

7. Hsu, A. Global Metrics for the Environment. Available online: www.epi.yale.edu (accessed on 24 May 2020).

8. Verchot, L.V.; Van Noordwijk, M.; Kandji, S.; Tomich, T.; Ong, C.; Albrecht, A.; Mackensen, J.; Bantilan, C.; Anupama, K.V.; Palm, C. Climate change: Linking adaptation and mitigation through agroforestry. Mitig. Adapt. Strat. Glob. Chang. 2007, 12, 901-918. [CrossRef]

9. Pezikoğlu, F. Sürdürülebilir tarım ve kırsal Kalkınma kavramı içinde tarım-turizm-kırsal alan ilişkisi ve sonuçları (Agriculture-tourism-rural area relationship and its results within the concept of sustainable agriculture and rural development). Karamanoğlu Mehmetbey Üniversitesi Sos. Ekon. Araştırmalar Derg. 2012, 14, 83-92.

10. FAO and ITPS. Status of the World's Soil Resources: Main Report, 1st ed.; FAO: Rome, Italy, 2015; ISBN 978-92-5-109004-6.

11. Paul, B.K.; Rashid, H. Nonstructural Adaptation. In Climatic Hazards in Coastal Bangladesh; Paul, B.K., Rashid, H., Eds.; Butterworth-Heinemann: Boston, MA, USA, 2017; pp. 209-256. ISBN 978-0-12-805276-1.

12. Imadi, S.R.; Shah, S.W.; Kazi, A.G.; Azooz, M.M.; Ahmad, P. Phytoremediation of Saline Soils for Sustainable Agricultural Productivity. In Plant Metal Interaction; Ahmad, P., Ed.; Elsevier: Oxford, UK, 2015; pp. 455-468. ISBN 978-0-12-803158-2.

13. Kalev, S.D.; Toor, G.S. The Composition of Soils and Sediments. In Green Chemistry; Török, B., Dransfield, T., Eds.; Elsevier: Cambridge, MA, USA, 2017; pp. 339-357. ISBN 978-0-12-809270-5.

14. Gupta, R.K.; Abrol, I.P. Salt-Affected Soils: Their Reclamation and Management for Crop Production. In Advances in Soil Science; Lal, R., Stewart, B.A., Eds.; Springer: New York, NY, USA, 1990; pp. 223-288. ISBN 978-1-4612-3322-0.

15. Artiola, J.F.; Walworth, J.L.; Musil, S.A.; Crimmins, M.A. Soil and Land Pollution. In Environmental and Pollution Science; Brusseau, M.L., Pepper, I.L., Gerba, C.P., Eds.; Academic Press: Cambridge, MA, USA, 2019; pp. 219-235. ISBN 978-0-12-814719-1.

16. Miransari, M. Arbuscular Mycorrhizal Fungi and Soil Salinity. In Mycorrhizal Mediation of Soil; Johnson, N.C., Gehring, C., Jansa, J., Eds.; Elsevier: Cambridge, MA, USA, 2017; pp. 263-277. ISBN 978-0-12-804312-7. 
17. Grieve, A.M.; Dunford, E.; Marston, D.; Martin, R.E.; Slavich, P. Effects of waterlogging and soil salinity on irrigated agriculture in the Murray Valley: A review. Aust. J. Exp. Agric. 1986, 26, 761-777. [CrossRef]

18. Kalkınma Bakanlığı. Tarım Arazilerinin Sürdürülebilir Kullanımı Çalışma Grubu Raporu (Sustainable Use of Agricultural Land Working Group Report), 1st ed.; Yayın No: 2860-ÖİK: 714; Kalkınma Bakanlı̆̆1: Ankara, Turkey, 2014; ISBN 978-605-4667-58-1.

19. GAP Regional Development Administration. What's GAP? Available online: http://www.gap.gov.tr/en/ (accessed on 3 July 2020).

20. Çă̆lak, S.; Özlü, T.; Gündüz, S. Şanlıurfa ili iklim özelliklerinin enterpolasyon teknikleri ile analizi (Analysis of climatic properties of Şanlıurfa province with interpolation techniques). Uluslararası Sos. Araştırmalar Derg. 2016, 9, 360-372.

21. Çelik, D. Harran Ovası'nda Reha Sulama Birliği Alanında Geri Dönüşüm Suyunun Toprakta Tuz Birikimine Etkisinin Mekânsal İnterpolasyon Teknikleri İle Haritalanması (Mapping The Effect of Salt Accumulation of Irrigation Return Flows Water at The Soil of Reha Irrigation Association of Harran Plainbyusing Gis Techniques). Master's Thesis, Harran Üniversitesi Fen Bilimleri Enstitüsü, Şanlıurfa, Turkey, 2018.

22. Anonymous. Doğal Kaynakların Planlanması ve Kontrolü (Planning and Control of Natural Resources). Available online: https://www.cografyabilimi.gen.tr/dogal-kaynaklarin-planlanmasi-kontrolu/ (accessed on 1 August 2020).

23. Cullu, M.A. Estimation of the effect of soil salinity on crop yield using remote sensing and geographic information system. Turk. J. Agric. For. 2003, 27, 23-28.

24. Paksoy, S.; Karlı, B. GAP kapsamında sulamaya açılan Harran Ovasındaki tarım işletmelerinin ekonomik analizi (Economic analysis of agricultural holdings in the GAP-Harran Plain irrigations). Balıkesir Üniversitesi Sos. Bilimler Enstitüsü Derg. 2000, 3, 154-175.

25. Yenigün, K.; Aydogdu, M.H. Evaluation of irrigation and drainage systems of GAP, the Turkey's largest integrated water resource development project. Sci. Res. Essays 2010, 5, 3237-3253.

26. Üzen, N.; Çetin, Ö.; Tarı, A. GAP bölgesinde sulamanın etkisi, sorunlar ve çözüm önerileri (The effects of irrigation, problems and solutions in the GAP region). Harran Tartm Gida Bilimleri Derg. 2015, 17, $37-42$.

27. Aydoğdu, M.; Aydoğdu, M.H.; Çullu, M.A. Farklı tuz seviyelerindeki toprakların pamuk verimine etkisinin belirlenmesi ve uydu verileriyle ilişkilendirilmesi-Şanlıurfa, Harran Ovası; İmambakır Sulama Birliği (Determination of the effect of soils at different salt levels on cotton yield and correlation with satellite data -Şanlıurfa, Harran Plain; Imambakir Irrigation Union). J. Turk. Stud. 2014, 9, 231-250. [CrossRef]

28. Aydoğdu, M.; Aydoğdu, M.H.; Çullu, M.A. Coğrafi bilgi sistemi (CBS) ve uzaktan algılama (UA) ile tuzluluğun etkisi altında pamukta verim kaybının belirlenmesi GAP bölgesi, Akçakale örneği, Türkiye (Determination of cotton yield loss under the influence of salinity with geographic information system (GIS) and remote sensing (UA) in GAP Region-Akçakale Sampling, Turkey). J. Acad. Soc. Sci. Stud. 2014, 24, 617-630. [CrossRef]

29. Bayram, N. Sosyal Bilimlerde SPSS ile Veri Analizi (Data Analysis with SPSS in Social Sciences), 6th ed.; Ezgi Kitabevi: Bursa, Turkey, 2017; ISBN 978-975-8606-43-3.

30. Briggs, D.C. Causal inference and the Heckman Model. J. Educ. Behav. Stat. 2004, 29, 397-420. [CrossRef]

31. Certo, S.T.; Busenbark, J.R.; Woo, H.; Semadeni, M. Sample selection bias and Heckman models in strategic management research. Strateg. Manag. J. 2016, 37, 2639-2657. [CrossRef]

32. Cançelik, M.; Aydogdu, M.H.; Sevinç, M.R. A research on the activities and problems of agro-based producers and breeder associations in Sanliurfa, Turkey. IOSR J. Bus. Manag. (IOSR-JBM) 2020, 22, 15-23. [CrossRef]

33. Xiong, K.; Kong, F.; Zhang, N.; Lei, N.; Sun, C. Analysis of the factors influencing willingness to pay and payout level for ecological environment improvement of the Ganjiang River Basin. Sustainability 2018, 10, 2149. [CrossRef]

34. Xiong, K.; Zhang, N.; Kung, C.-C.; Kong, F. Determinants of residents' willingness to accept and their levels for ecological conservation in Ganjiang River Basin, China: An empirical analysis of survey data for 677 households. Sustainability 2019, 11, 6138. [CrossRef]

35. Kyaw, N.N.; Ahn, S.; Lee, S.H. Analysis of the factors influencing market participation among smallholder rice farmers in Magway Region, central dry zone of Myanmar. Sustainability 2018, 10, 4441. [CrossRef]

36. Doğan, H.P.; Aydoğdu, M.H.; Sevinç, M.R.; Cançelik, M. Farmers' willingness to pay for services to ensure sustainable agricultural income in the GAP-Harran Plain, Şanlıurfa, Turkey. Agriculture 2020, 10, 152. [CrossRef] 
37. Greene, W.H. Econometric Analysis, 5th ed.; Pearson Education: New York, NY, USA, 2002; ISBN 0-13-066189-9.

38. Sartori, A.E. An estimator for some binary-outcome selection models without exclusion restrictions. Political Anal. 2003, 11, 111-138. [CrossRef]

39. Lee, L.-F. Self-Selection. In A Companion to Theoretical Econometrics; Baltagi, B.H., Ed.; Blackwell Publishing: Oxford, UK, 2001; pp. 383-409. ISBN 0-631-21254-X.

40. Anonymous. 2018 USD-Dollar Exchange Rates. Available online: https://paracevirici.com/doviz-arsiv/ merkez-bankasi/gecmis-tarihli-doviz/2018/amerikan-dolari (accessed on 19 May 2020).

41. Aydogdu, M.H. Farmers' risk perception and willingness to pay for environment: Case study of GAP-Sanliurfa, Turkey. Fresenius Environ. Bull. 2016, 25, 5449-5455.

42. Hayran, S.; Gül, A.; Sarıdaş, M.A. Farmers' sustainable agriculture perception in Turkey: The case of Mersin province. New Medit 2018, 3, 69-78. [CrossRef]

43. Di Pietro, F. Assessing ecologically sustainable agricultural land-use in the Central Pyrénées at the field and landscape level. Agric. Ecosyst. Environ. 2001, 86, 93-103. [CrossRef]

44. Ning, J.; Jin, J.; Kuang, F.; Wan, X.; Zhang, C.; Guan, T. The valuation of grassland ecosystem services in Inner Mongolia of China and its spatial differences. Sustainability 2019, 11, 7117. [CrossRef]

45. TUIK. Agricultural Enterprise Structure Research. 2016. Available online: http://www.tuik.gov.tr/HbPrint. do?id=24869 (accessed on 25 May 2020).

46. Yang, X.; Zhang, A.; Zhang, F. Farmers' heterogeneous willingness to pay for farmland non-market goods and services on the basis of a mixed logit model-A case study of Wuhan, China. Int. J. Environ. Res. Public Health 2019, 16, 3876. [CrossRef]

47. Mutaqin, D.J.; Usami, K. Smallholder farmers' willingness to pay for agricultural production cost insurance in rural West Java, Indonesia: A contingent valuation method (CVM) approach. Risks 2019, 7, 69. [CrossRef]

48. Ulimwengu, J.; Sanyal, P. Joint Estimation of Farmers' Stated Willingness to Pay for Agricultural Services. Available online: https://core.ac.uk/download/pdf/6237697.pdf (accessed on 18 March 2020).

49. Lin, H.-I.; Liou, J.-L.; Hsu, S.-H. Economic valuation of public meteorological information services-A case study of agricultural producers in Taiwan. Atmosphere 2019, 10, 753. [CrossRef]

50. Değirmenci, Y.; Manyaz, İ.; Güzelaydın, İ.; Erkuş, E.; Koçak, E.; Arı, B. Tarımsal Yayım ve Danışmanlık (Agricultural Extension and Consultancy), 1st ed.; T.C. Gıda Tarım ve Hayvancılık Bakanlığı; Eğitim Yayım ve Yayınlar Dairesi Başkanlığı: Ankara, Turkey, 2012.

51. Maghsood, F.F.; Moradi, H.; Berndtsson, R.; Panahi, M.; Daneshi, A.; Hashemi, H.; Bavani, A.R.M. Social acceptability of flood management strategies under climate change using contingent valuation method (CVM). Sustainability 2019, 11, 5053. [CrossRef]

52. Burch, C.; Busch, M.; Higgins, E.; Bittner, S.; Perera, N.; Neal, K.; Burkett, L.; Castro, A.J.; Anderson, C. Revisiting a water conflict in Southeastern Oklahoma 6 Years Later: A new valuation of the willingness to pay for ecosystem services. Sustainability 2020, 12, 819. [CrossRef]

53. Aydogdu, M.H.; Bilgic, A. An evaluation of farmers' willingness to pay for efficient irrigation for sustainable usage of resources: The GAP-Harran Plain case, Turkey. J. Integr. Environ. Sci. 2016, 13, 175-186. [CrossRef]

54. Fouepe, G.H.F.; Mbangari, K.F. Contributions of farmers organizations to rural development: Case of North West farmers organization in Mezam Division, Cameroon. J. Agric. Ext. Rural Dev. 2017, 9, 129-142. [CrossRef]

55. Menozzi, D. Extra-virgin olive oil production sustainability in northern Italy: A preliminary study. Br. Food J. 2014, 116, 1942-1959. [CrossRef]

56. Aydoğ, M.H.; Aydoğdu, İ.; Cevheri, C.; Sevinç, M.R.; Küçük, N. Şanlıurfa'daki yem bitkileri eken çiftçilerin sosyo-ekonomik profilinin analizi (Analysis of the socio-economic profile of farmers who plant forage crops in Şanlıurfa). Türkiye Ekonomisi Özel Sayısı Special Issue Turkey Economy. J. Ekon. 2020, 10-15. Available online: https://dergipark.org.tr/tr/pub/ekonomi/issue/47196/707959 (accessed on 1 August 2020).

(C) 2020 by the authors. Licensee MDPI, Basel, Switzerland. This article is an open access article distributed under the terms and conditions of the Creative Commons Attribution (CC BY) license (http://creativecommons.org/licenses/by/4.0/). 